\title{
ANALISIS PEMBELAJARAN DARING TERHADAP PRESTASI MAHASISWA MANAJEMEN UNIVERSITAS PAMULANG DI ERA NEW NORMAL
}

\author{
${ }^{1 *}$ Dewi Nari Ratih Permada, ${ }^{2}$ Yhonanda Harsono \\ Universitas Pamulang, Tangerang Selatan, Banten, Indonesia \\ *dewi.permada00821@unpam.ac.id
}

\begin{abstract}
Abstrak
Tujuan penelitian ini adalah untuk mengetahui bagaimana pengaruh pembelajaran daring dan prestasi mahasiswa Manajemen Universitas Pamulang di Era new normal. Sifat penelitian ini adalah asosiatif kuantitatif. Berdasarkan hasil uji $\mathrm{F}$ pada tabel di atas antara variabel bebas terhadap variabel terikat diperoleh tingkat signifikan 0,000 < 0,05 maka H0 ditolak dan H1 diterima. Dengan demikian, Model regresi linier sederhana pada penelitian ini memiliki pengaruh dan dari pemaparan hasil analisis yang telah dilakukan, dapat disimpulkan bahwa terdapat pengaruh pembelajaran daring mahasiswa terhadap prestasi mahasiswa manajemen Universitas Pamulang di masa New Normal walaupun variabel pembelajaran daring hanya dapat memprediksi $14,5 \%$ terhadap prestasi mahasiswa manajemen Universitas Pamulang di masa New Normal saat ini.
\end{abstract}

Kata Kunci: Pandemi Covid-19, Metode Daring, Prestasi Mahasiswa

\section{Abstract}

The purpose of this study is to find out how the influence of online learning and the achievements of Pamulang University Management students in the new normal era. The nature of this research is quantitative associative. Based on the results of the $F$ test in the table above between free variables against bound variables obtained a significant rate of $0.000<0.05$ then $\mathrm{H} 0$ is rejected and $\mathrm{H} 1$ is accepted. Thus, the simple linear regression model in this study has an influence and from the presentation of the results of the analysis that has been done, it can be concluded that there is an influence of student online learning on the achievement of Pamulang University management students in the New Normal period although online learning variables can only predict $14.5 \%$ of the achievement of Pamulang University management students in the current New Normal period.

Keywords: Pandemic Covid-19, Online Methods, Student Achievement

\section{PENDAHULUAN}

Dampak dari pandemi covid-19 ini sangat kita rasakan bersama, terutama sektor ekonomi, sektor pendidikan, sektor sosial dan budaya. Saat ini masih ada beberapa daerah yang menerapkan kembali pembatasan sosial berskala besar (PSBB) seperti DKI Jakarta melalui Peraturan Gubernur (Pergub) Nomor 88 Tahun 2020 [1]. Gubernur DKI Jakarta Anies Baswedan menegaskan PSBB tetap berlaku mulai 14 September 2020. Daerah sekitar DKI Jakarta pun menerapkan jam malam seperti kota Depok, Kota Bogor menerapkan jam malam, dilansir dari beritasatu.com.

Dampak pandemi covid-19 dirasakan juga di sektor pendidikan, dimana sejak kuartal pertama sudah di tetapkan PSBB hampir di seluruh daerah di Indonesia, sehingga sampai saat ini kegiatan belajar mengajar mulai dari tingkat dasar sampai tingkat universitas dilakukan secara online (daring). Kemendikbud melalui laman resminya menyatakan bahwa 57\% (238 Kab/Kota) peserta didik berada dalam zona merah dan orange, dan sisanya $43 \% \quad(276$ $\mathrm{Kab} /$ kota) berada pada zona hijau dan kuning, sehingga sangat disarankan agar belajar dilakukan dari rumah (BDR) [3]. Pun dalam Keputusan Bersama Nomor 03/KB/2020 Nomor 612 Tahun 2020 Nomor HK.01.08/Menkes/502/2020 Nomor 119/4536/SJ tentang Panduan Penyelenggaraan Pembelajaran Pada 
Tahun Ajaran 2020/2021 Dan Tahun Akademik 2020/2021 Di Masa Pandemi Corona virus Disease 2019 (Covid-19) yang intinya adalah pembelajaran yang dilakukan kepada anak didik melalui BDR, adapun untuk zona hijau atau kuning dapat melakukan pembelajaran tatap muka dengan ketentuan yang sangat ketat agar tidak terjadi penyebaran wabah covid-19 secara lebih luas lagi [4]

Selama pandemi ini, mahasiswa dihadapkan pada pembelajaran daring, mau tidak mau, suka atau tidak suka mereka harus melalui transfer ilmu pengetahuan melalui sistem daring. Dalam situasi seperti ini kemungkinan banyak hambatan yang bisa dialami mahasiswa seperti tidak memahami materi yang diberikan, tidak dapat berdiskusi dengan leluasa, keterbatasan data yang mereka miliki untuk mengakses materi dan informasi, kesulitan dalam mengatur waktu belajar secara efisien, malas untuk membaca dan diskusi memecahkan masalah pada tugas mereka, malas bertanya kepada dosen pengajar dan lainlain sehingga hal ini bisa menyebabkan prestasi belajar mereka turun. Permasalaha ini lah yang akan diteliti dalam penelitian ini.

Penelitian sebelumnya oleh Nugroho et al., (2020) [5] dengan judul Analisis Pengaruh Pandemi Dan Pembelajaran Secara Daring Terhadap Prestasi Melalui Variabel Intervening Keadaan Ekonomi Mahasiswa Universitas Sangga Buana YPKP Bandung menghsilkan pandemic, pembelajaran daring, dan keaddan ekonomi berpengaruh simultan terhadap prestasi belajar dengan pengaruh secara total sebesar $87,7 \%$ terhadap prestasi belajar, sedangkan sebagai intervening keadaan ekonomi berpengaruh sebesar $15,5 \%$ terhadap prestasi belajar. Penelitian selanjutnya oleh Dewi, E. U. (2020) [6] yang berjudul Pengaruh Kecemasan Saat Pembelajaran Daring Masa Pandemi Covid-19 Terhadap Prestasi Belajar Mahasiswa Stikes William Surabaya dimana hasilnya adalah ada pengaruh antara kecemasan selama pembelajaran daring terhadap prestasi belajar mahasiswa. Harapani, A. (2021) [7] dalam penelitian berjudul Pengaruh Kuliah Daring Saat Pandemi Covid-19 Terhadap Kemampuan Mahasiswa menghasilkan bahwa kuliah daring berpengaruh terhadap kemampuan mahasiswa. Dari dasar penelitian sebelumnya inilah, akan digali lebih lanjut mengenai apa saja yang menjadi kendala dan apa saja yang mempengaruhi kemampuan mahasiswa serta kondisi metode daring yang ada apa saat pandemi covid-19 terhadap prestasi mahasiswa khususnya di Universitas Pamulang.

Dengan kondisi seperti ini, sektor pembelajaran khususnya di kampus Universitas Pamulang yang memiliki mahasiswa aktif kurang lebih 12.000 Mahasiswa sangat berdampak terhadap kualitas pembelajaran yang berimbas pada prestasi mahasiswa itu sendiri. Kami tertarik untuk melakukan penelitian seputar pembelajaran dari rumah untuk mencegah penyebaran covid-19 lebih buruk lagi namun disatu sisi, peningkatan prestasi mahasiswa tetap diperhitungkan. Penelitian ini akan menganalisis mengenaipembelajaran daring di era new normal terhadap prestasi mahasiswa Manajemen Universitas Pamulang tahun 2020 ini. Apakah prestasi Mahasiwa meningkat, menurun atau stabil selama pembelajaran via daring. Maka peneliti ingin membuat penelitian dengan judul "Analisis Pembelajaran Daring terhadap Prestasi Mahasiswa Manajemen Universitas Pamulang di Era New Normal".

\section{TINJAUAN PUSTAKA}

\section{Pembelajaran Metode Daring (dalam jaringan)}

Kata daring berasal dari dua kata yaitu dalam dan jaringan. Menurut Isman (2016)[10] pembelajaran daring merupakan suatu proses pembelajaran yang memanfaatkan jaringan internet saat pelaksanaannya. Pembelajaran Daring Learning sendiri dapat di pahami sebagai pendidikan formal yang diselenggarakan 
oleh sekolah yang peserta didiknya dan instrukturnya (guru) berada di lokasi terpisah sehingga memerlukan sistem telekomunikasi interkatif sebagai media penghubung keduanya dan berbagai sumber daya yang diperlukan didalamnya (Sobron dkk, 2019)[11].

Sebelum pandemi covid-19 pembelajaran melalui e-learning berkisar $30 \%$ dari jumlah pertemuan tatap muka dalam satu semester, namun setelah pandemi covid-19 diputuskan pembelajaran melalui metode daring elearning $100 \%$. Guna menambah pemahaman mahasiswa dalam menerima materi pembelajaran, sebagian dosen menyediakan kesediaan waktu, tenaga dan lain-lain untuk melakukan pembelajaran melalui aplikasi zoom, google meet dan sebagainya. Dengan aplikasi zoom dan google meet mahasiswa bisa bertatap muka langsung dengan dosen walaupun secara virtual di layar gagdet masingmasing. Namun karena keterbatasan kuota yang dimiliki mahasiswa maka tidak semua mahasiswa bisa mengikuti pembelajaran tambahan melalui aplikasi zoom dan google meet.

Prestasi

Menurut Sumadi (2012)[17], “Prestasi Belajar sebagai nilai yang merupakan bentuk perumusan akhir yang diberikan oleh guru terkait dengan kemajuan atau Prestasi Belajar siswa selama waktu tertentu". Bukti keberhasilan dari seseorang setelah memperoleh pengalaman belajar atau mempelajari sesuatu merupakan Prestasi Belajar yang dicapai oleh siswa dalam waktu tertentu. Hasil belajar atau achievement merupakan realisasi atau pemekaran dari kecakapankecakapan potensial atau kapasitas yang dimiliki oleh seseorang. Penguasaan hasil belajar oleh seseorang dapat dilihat dari perilakunya, baik perilaku dalam bentuk penguasaan pengetahuan, keterampilan berpikir maupun keterampilan motorik.Berdasarkan uraian di atas dapat disimpulkan bahwa Prestasi Belajar dapat dipengaruhi oleh dua faktor yaitu; faktor internal yakni faktor yang muncul dari dalam diri individu yang berupa faktor jasmaniah (kesehatan dan cacat tubuh), faktor psikologis (intelegensi, perhatian, minat, bakat, motif, kematangan, kesiapan, kecerdasan, latihan, motivasi dan faktor pribadi) dan faktor kelelahan, Faktor eksternal yakni kondisi lingkungan di sekitar siswa diantaranya lingkungan sosial seperti lingkungan sosial sekolah yang di dalamnya termasuk metode mengajar, kurikulum, relasi guru dengan siswa, relasi siswa dengan siswa, disiplin sekolah, alat pelajaran, waktu sekolah, standar pelajaran di atas ukuran keadaan gedung, metode belajar, tugas rumah.

\section{METODE}

Dalam penelitian ini metode penelitian yang digunakan adalah metode penelitian kuantitatif. Menurut Sugiyono (2017][21] "Metode penelitian kuantitatif dapat diartikan sebagai metode penelitian yang berlandaskan pada filsafat positivisme, digunakan untuk meneliti populasi atau sampel tertentu, pengumpulan data menggunakan instrumen penelitian, analisis data bersifat kuantitatif, dengan tujuan untuk menguji hipotesis yang telah ditetapkan. Sesuai dengan judul penelitian ini yaitu Analisis Pembelajaran Daring terhadap Prestasi Mahasiswa Manajemen Universitas Pamulang di Era New Normal, maka populasi yang diambil adalah seluruh Mahasiswa Manajemen dengan jumlah 12.000 Mahasiswa. Jumlah sampel sebanyak 100 orang dengan batas toleransi kesalahaan sebesar $10 \%$.

\section{HASIL DAN PEMBAHASAN}

\section{Uji Asumsi Klasik}

Dikarenakan penilitian ini menggunakan model regresi linear, maka syarat yang harus dipenuhi untuk analisis regresi menurut Ghozali (2011), terlebih dahulu melakukan uji asumsi klasik, pengujian asumsi klasik yang digunakan dalam penelitian ini yaitu uji normalitas, uji multikolinearitas, uji heteroskedastisitas, uji autokorelasi. 
Berikut ini adalah hasil uji asumsi klasik dalam penelitian :

\section{a. Uji Normalitas}

Untuk mengetahui pola dan varian serta kelineritasan dari suatu populasi. Apakah populasi atau data terdistribusi normal atau tidak, ada dua cara mendeteksi apakah residual memiliki distibusi normal atau tidak. Hasil uji normalitas yang diperoleh dari hasil olahan adalah memiliki kecenderungan membentuk kurva normal karena diagram menunjukkan distribusi data residualnya mengikuti alur garis. Maka diagram tersebut telah memenuhi asumsi normalitas. Berdasarkan gambar grafik normal probability plot terlihat data menyebar disekitar diagonal dan mengikuti arah garis. Meskipun data sedikit keluar garis dan kemudian mengikuti kembali garis diagonalnya, data observasi penelitian dikatakan memiliki distribusi normal.

\section{b. Uji F (simultan)}

Pengujian secara simultan dilakukan dengan menggunakan uji F. Uji F dilakukan untuk mengetahui apakah semua variabel independen pengaruh terhadap variabel dependen. Perumusan hipotesa untuk Uji F, yaitu :H0: Model regresi linier tidak memiliki pengaruhH1: Model regresi linier memiliki pengaruh.

Dasar pengambilan keputusan pada Uji F, yaitu :

1. Jika $\mathrm{F}$ hitung $>\mathrm{F}$ tabel (Ho ditolak mempunyai pengaruh signifikan).

2. Jika F hitung $<\mathrm{F}$ tabel (Ho diterima tidak mempunyai pengaruh signifikan).

Atau

1. Jika Sig. F statistik $<0,05$ (Ho ditolak ; signifikan secara statistik)
2. Jika Sig. F statistic $>0,05$ (Ho diterima : tidak signifikan secara statistik)

Berdasarkan hasil uji $\mathrm{F}$ pada tabel di atas antara variabel bebas terhadap variabel terikat diperoleh tingkat signifikan 0,000 $<0,05$ maka H0 ditolak dan H1 diterima. Dengan demikian, Model regresi linier sederhana pada penelitian ini memiliki pengaruh. Berdasarkan tabel persamaan regresi linier maka diperoleh persamaan regresi sebagai berikut:

$$
Y=13.208+0.357 X
$$

1. Nilai koefisien konstanta sebesar 13.208 dan berarah positif artinya bila besarnya variabel $X$ bernilai 0 maka secara rata-rata $\mathrm{Y}$ memiliki nilai sebesar 13.208. Sebagai gambaran bahwa $Y$ dan $X$ adalah jumlah dari jawaban responden pada masing-masing indikatornya. Jika Y bernilai 13,208 dengan jumlah pertanyaan 5, maka secara rata-rata jawaban Y dari responden sebesar 2,6416 atau berada pada jawaban "Tidak Setuju" hingga Netral.

2. Koefisisen regresi variabel $X$ bernilai positif yaitu 0.357 . Hal ini menunjukan bahwa ketika $X$ mengalami kenaikan, maka $Y$ juga akan mengalami peningkatan dengan asumsi variabel lain tetap.

Dalam perumusan hipotesa untuk Uji-t, yaitu :

H0: Tidak terdapat pengaruh yang signifikan antara variabel bebas terhadap variabel terikat.

H1: Terdapat pengaruh yang signifikan antara variabel bebas terhadap variabel terikat

Dasar pengambilan keputusan Uji-t, yaitu :

1. Jika $t$ hitung $>t$ tabel (Ho ditolak : ada pengaruh signifikan).

2. Jika $\mathrm{t}$ hitung $<\mathrm{t}$ tabel (Ho diterima ; tidak ada pengaruh signifikan). 
Atau

1. Jika nilai Sig. $<0,05$ (Ho ditolak: signifikan secara statistik).

2. Jika nilai Sig. $>0,05$ (Ho diterima : tidak signifikan secara statistik)

Berdasarkan table dan kriteria keputusan Uji-t, maka dapat disimpulkan bahwa variabel $X$ memiliki pengaruh terhadap Y karena memiliki signifikansi < 0,05 . Artinya terdapat pengaruh yang signifikan antara pembelajaran daring terhadap prestasi mahsiswa.

\section{HASIL UJI KOEFISIEN DETERMINASI}

Berdasarkan hasil tabel di atas menunjukkan bahwa uji tersebut $\mathrm{R}$ Square sebesar 0,145, nilai ini menunjukkan bahwa variabel independent memberikan informasi untuk memprediksi variabel dependen sebesar 14,5\%. Sehingga masih ada variabel lain untuk mempengaruhi terhadap financial distress sebesar $85,5 \%$.

\section{KESIMPULAN DAN SARAN Kesimpulan}

Dari pemaparan hasil analisis yang telah dilakukan, dapat disimpulkan bahwa terdapat pengaruh pembelajaran daring mahasiswa terhadap prestasi mahasiswa manajemen Universitas Pamulang di masa New Normal walaupun variabel pembelajaran daring hanya dapat memprediksi $14,5 \%$ terhadap prestasi mahasiswa manajemen Universitas Pamulang di masa New Normal saat ini.

\section{Saran}

a) Dalam rangka meningkatkan prestasi mahasiswa manajemen di Universitas Pamulang, masih dapat diraih selain dari pembelajaran daring, seperti belajar kelompok, sharing session mengenai materi pembalajaran sesama mahasiswa, kerja kelompok menyelesaikan tugas dan lain-lain.

b) Besar harapan kami sebagai dosen manajemen di Univesrsitas Pamulang dapat lebih memberikan kontribusi di masa New Normal dengan meningkatkan komunikasi dua arah antara dosen dan mahasiswa sehingga dapat tercipta suasana belajar yang lebih mendukung walaupun tidak langsung bertemu secara tatap muka.

\section{DAFTAR PUSTAKA}

Alisman. 2014. Analisis Efektivitas dan Efisiensi Manajemen Keuangan di Aceh Barat. Jurnal Ekonomi dan Kebijakan Publik Indonesia. 50 Robbins, Stephen P.; Judge, Timothy A. (2008). Perilaku Organisasi Buku 1, Jakarta: Salemba Empat. Hal.5666).

Aprida, P., \& Muhammad Darwis, D. 2017. Belajar dan Pembelajaran. Fitrah Jurnaljurnal Keilmuan, 337

Ar-ruzzmedia. Putra, Made. 2020. Kurang Efisiennya PembelajaranDaring/ELearning.3

Basrowi dan Suwandi. 2008. Memahami Penelitian Kualitatif. Jakarta: Rineka Cipta.

Bilfaqih, Yusuf. 2015. Esesnsi Pengembangan Pembelajaran Daring.Yogyakarta: Deepublish

Dunnette, M. D. (Inggris)"Aptitude, Abilities, and Skills," Handbook of Industrial and Organizational Psychology, Chicago: Rand McNally, 1976, hal. 478-483.

Hasan, M. Iqbal. 2002. Pokok-Pokok Materi Metodologi Penelitian dan Aplikasinya. Jakarta: Ghalia Indonesia Weiner, B. (1990). History of motivational research in education. Journal of educational Psychology, 82(4), 616.

Imron, m. (2017). Pengaruh motivasi dan kompensasi terhadap prestasi kerja karyawan cleaning service PT Etos nasional indonesia (studi kasus di rsud kepanjen malang).

Isman, Mhd. 2016. Pembelajaran Media dalam Jaringan (Moda Jaringan). The Progressive and Fun Education Seminar, 586.

Jamaludin, Dindin dkk. 2020. Pembelajaran Daring Masa Pandemik Covid-19 Pada Calon Guru: Hambatan, Solusi Dan Proyeksi. Karya Tulis Ilmiah 
LP2M UIN Sunan Gunung Djati Bandung. 3

Masruri. 2014. Analisis Efektifitas Program Nasional Pemberdayaan Masyarakat Mandiri Perkotaan.Padang: Akademia Permata

Mitchell, T. R. Research in Organizational Behavior. Greenwich, CT: JAI Press, 1997, hal. 60-62.

Mutia, Intan dan Leonard. 2013. Kajian Penerapan E-learning Dalam Proses Pembelajaran di Perguruan Tinggi. Faktor Exacta 6(4). 282

Nurkholis. 2013. Pendidikan Dalam Upaya Memajukan Teknologi. Jurnal Kependidikan, 25.Pengetahuan. 131

Pangondian, Roman A. 2019. Faktor-Faktor Yang Mempengaruhi Kesuksesan Pembelajaran Daring Dalam Revolusi Industri 4.0. Seminar Nasional Teknologi Komputer \& Sains (SAINTEKS). 57

Prastowo, Andi. 2012. Metode Penelitian Penelitian Kualitatif Dalam Persektif Rancangan Penelitian. Jogjakarta :

Putra, Made. 2020. Kurang Efisiennya PembelajaranDaring/E-Learning.3

Rohmawati, Afifatu. 2015. Efektivitas Pembelajaran. Jurnal Pendidikan Usia Dini, 17.

Syarifudin, Albitar S. 2020. Implementasi Pembelajaran Daring Untuk Meningkatkan Mutu Pendidikan Sebagai Dampak Diterapkannya Social Distancing. Jurnal Pendidikan Bahasa dan Sastra Indonesia. 31-33
Sobron A.N, B. R. 2019. Persepsi Siswa dalam Studi Pengaruh Daring Learning terhadap Minat Belajar IPA. Pendidikan Islam dan Multikulturalisme.

Sugiyono. 2015. Metode Penelitian Kombinasi (Mix Methods). Bandung: Alfabeta

Uno, H. B. (2007). Model pembelajaran menciptakan proses belajar mengajar yang kreatif dan efektif. Jakarta: Bumi Aksara.

Gubernur (Pergub) DKI Jakarta Nomor 88 Tahun 2020.

https://www.beritasatu.com/herisoba/nasional/673285/pemberlakua n-jam-malam-di-wilayahpenyangga-jakarta Diakses tanggal 28 September 2020.

https://www.kemdikbud.go.id/Diakses tanggal 28 September 2020.

Keputusan Bersama Menteri Pendidikan Dan Kebudayaan, Menteri Agama, Menteri Kesehatan, Dan Menteri Dalam Negeri Republik Indonesia Nomor 03/KB/2020 Nomor 612 Tahun $2020 \quad$ Nomor HK.01.08/Menkes/502/2020 Nomor 119/4536/SJ tentang Panduan Penyelenggaraan Pembelajaran Pada Tahun Ajaran 2020/2021 Dan Tahun Akademik 2020/2021 Di Masa Pandemi Coronavirus Disease 2019 (Covid-19). 